\title{
Geografi Emosi Tentang COVID-19 pada Pelajar
}

\author{
Emotional Geography About COVID-19 In Students
}

\author{
Septian Andriyani ${ }^{1}$, Upik Rahmi ${ }^{1}$, Afianti Sulastri ${ }^{1}$, Dadang Darmawan ${ }^{2}$ \\ ${ }^{1}$ Universitas Pendidikan Indonesia, ${ }^{2}$ Akademi Keperawatan RS. Dustira
}

${ }^{*}$ Korespodensi Penulis :

Septian Andriyani

Email : septianandriyani@upi.edu

\begin{abstract}
Abstrak
Latar Belakang : Corona virus 2019 (COVID-19) merupakan salah satu jenis virus yang disebabkan oleh Severe Acute Respiratory Syndrome Coronavirus-2 (SARS-CoV-2), telah muncul sebagai ancaman kesehatan global Indonesia menjadi salah satu negara yang terkena dampak dari pandemi COVID-19. Selama masa pandemi banyak orang menunjukkan respon yang terkait dengan stres atau kecemasan. Anak -anak dan remaja mengalami kecemasan, takut, merasa tertekan, merasa tidak tenang, dan khawatir sehingga dapat menyebabkan gangguan emosi. Adapun tujuan dari penelitian ini adalah untuk mengidentifikasi geografi emosi tentang COVID-19 pada siswa SMPN VIII di Kota Cimahi. Metode : Desain penelitian yang digunakan adalah deskriptif kuantitatif. Teknik pengumpulan data menggunakan google form yang disebar secara online kepada siswa. Alat pengumpulan data yang digunakan adalah mengacu kepada instrumen standar COVID Stress Scales (CSS) 2020 dengan 36 item pernyataan. Hasil : geografi emosi siswa paling tinggi berada pada domain Xenophobia dengan nilai rata-rata sebesar 3,394 , selanjutnya adalah domain danger dengan nilai rata-rata 3,327. Untuk nilai rata rata yang paling rendah yaitu berada pada domain Compulsive Checking dengan nilai rata-rata 2,107. Selama pandemi nilai rata-rata geografi emosi tertinggi berada pada domain ketakutan (xenophobia). Kesimpulan : Xenophobia dalam ancaman penyebaran COVID-19 dapat meningkatkan ketakutan membawa penyakit sehingga mengarah pada penurunan kesejahteraan secara emosi. Pentingnya dapat meningkatkan kesejahteraan di masa pandemic COVID-19.
\end{abstract}

Kata kunci: Geografi Emosi, COVID-19, Siswa

\begin{abstract}
Background: Corona virus 2019 (COVID-19) is a type of virus caused by Severe Acute Respiratory Syndrome Coronavirus-2 (SARS-CoV-2), has emerged as a global health threat. Indonesia is one of the countries affected by the COVID-19 pandemic. During a pandemic, many people exhibit responses related to stress or anxiety. Children and adolescents experience anxiety, fear, feeling depressed, feeling uneasy, and worried so that it can cause emotional disturbances. The purpose of this study was to identify the emotional geography of COVID-19 in SMPN VIII students in Cimahi City. Method: The research design used is descriptive quantitative. Data collection techniques using google forms which are distributed online to students. The data collection tool used refers to the 2020 COVID Stress Scales (CSS) standard instrument with 36 statement items. Results: The results showed that the highest student's emotional geography was in the Xenophobia domain with an average value of 3,394, then the danger domain with an average value of 3,327. The lowest average value is in the Compulsive Checking domain with an average value of 2.107. During the pandemic, the highest average emotional geography score was in the domain of fear (xenophobia). Conclusion: Xenophobia in the threat of the spread of COVID-19 can increase the fear of carrying disease so that it leads to a decrease in emotional well-being. The importance of being able to improve welfare during the COVID-19 pandemic.
\end{abstract}

Keywords: Geography of Emotions, COVID-19, Students 
Pendahuluan

Pandemi merupakan kondisi penyebaran jenis penyakit tertentu yang terjadi lebih dari satu negara. Wabah ini telah menyebar hampir seluruh bagian wilayah di dunia. Kondisi pandemi menggambarkan suatu keadaan penyebaran penyakit yang di luar kendali. Penyebaran Corona virus Disease 2019 (COVID-19) melebihi kapasitas epidemi. Hal tersebut menjadikan status penyebaran COVID19 telah menjadi wabah pandemi. ${ }^{1}$ COVID-19 yang berasal dari Kota Wuhan Negara Cina ini ditemukan pada akhir tahun 2019. Virus ini menyebabkan penyakit pada saluran pernapasan. Penyakit yang disebabkan COVID-19 ini menyebar secara rapid atau cepat. World Health Organization (WHO) pada tanggal 12 Maret 2020 menetapkan bahwa fenomena penyebaran COVID-19 ini menjadi pandemi. $^{2}$

Penyebaran COVID-19 sangat cepat hingga pada 7 Mei 2020 WHO memaparkan tentang data penyebaran COVID-19 secara global. Menurut data tersebut terdapat 215 negara yang terkonfirmasi terkena dampak dari pandemi COVID-19. Berdasarkan data tersebut jumlah penderita sudah mencapai 3.634.172 orang positif dan 251.446 meninggal. ${ }^{3}$ WHO menyatakan penyakit COVID-19 ini sebagai pandemi dunia. $^{4}$

Indonesia menjadi salah satu negara yang terkena dampak dari pandemi COVID-19. Kasus penyebaran COVID-19 telah menyebar pada 350 kabupaten/kota di 34 Provinsi. Total 12.776 orang terkonfirmasi positif, 2.381 orang telah sembuh dan 930 orang meninggal hingga Mei 2020. Berdasarkan dari penyebaran virus yang sangat cepat dan banyak orang yang terkena dampak maka membutuhkan penanganan yang cepat. $^{3}$

Cimahi merupakan salah satu kota di Jawa Barat dengan angka kejadian COVID cukup tinggi. Berdasarkan data tanggal 25 Agustus 2020 bahwa kejadian kontak erat sebanyak 6360 orang, suspek 1089 orang, konfirmasi positif 171 orang. Dalam hal ini Konfirmasi positif COVID yang paling banyak berada di Kecamatan Cimahi Selatan yaitu sebanyak 61 orang, Cimahi Tengah 57 orang, Cimahi Utara 53 orang. ${ }^{5}$ Adapun salah satu sekolah menengah Pertama Negeri yang berada diwilayah Cimahi Selatan yaitu SMPN 8 Kota Cimahi dengan jumlah siswa 1640 orang dengan jumlah kelas 38 kelas dari kelas 7 sampai kelas 9 . Hal ini beresiko walaupun anak-anak belajar dari rumah, karena siswanya mayoritas bertempat 
tinggal didaerah kecamatan Cimahi Selatan.

Berdasarkan penelitian di Cina menunjukkan bahwa lebih dari $25 \%$ dari populasi umum mengalami tingkat stres yang berhubungan dengan gejala stres sedang atau berat dalam menanggapi COVID19. ${ }^{6,7}$ Temuan ini mirip dengan yang dilaporkan selama wabah SARS ${ }^{8}$, dan pandemi $\mathrm{H} 1 \mathrm{~N} 1^{9,10}$ Studi epidemi dan pandemi sebelumnya menunjukkan bahwa kecemasan, merupakan pendorong perilaku yang penting. Orang dengan kecemasan ringan kemungkinannya akan lebih terlibat dalam melakukan perilaku kebersihan seperti mencuci tangan, lebih kecil kemungkinan untuk mematuhi menjaga jarak secara fisik, dan melakukan untuk mendapatkan vaksinasi jika vaksin tersedia. ${ }^{11} \mathrm{Di}$ sisi lain, orang dengan kecemasan berlebihan cenderung terlibat dalam perilaku sosial yang berlebihan, seperti membeli stok barang atau makanan yang banyak, panik dan sering pergi ke rumah sakit atau klinik ketika salah mengartikan penyakit ringan sebagai tanda-tanda infeksi yang serius. ${ }^{12}$

Anak-anak menginginkan belajar dikelas dan merasa khawatir tentang masa depan. ${ }^{13}$ Anak -anak dan remaja yang mengalami cemas, takut, tertekan, merasa tidak tenang, dan khawatir. Hal tersebut termasuk kedalam kategori emosi. Emosi adalah perwujudan apa yang dirasakan seseorang sebagai reaksi terhadap suatu peristiwa atau situasi tertentu. Emosi tersebut memiliki unsur fisiologis kognitif, perilaku, dan pengalaman subjektif. Secara garis besarnya emosi digolongkan menjadi dua golongan yaitu emosi positif dan emosi negatif. Emosi positif seperti bahagia, senang, gembira dan cinta; sedangkan emosi negatif seperti marah, takut, sedih dan cemas. ${ }^{14}$

Berdasarkan fenomena diatas, peneliti sangat tertarik untuk melakukan penelitian tentang geografi emosi tentang COVID-19 pada siswa SMPN VIII di Kota Cimahi. Mengingat stres atau kecemasan merupakan hal yang sangat penting, jangan sampai berlarut-larut karena dapat berpengaruh terhadap kesehatan fisik dan mental anak. Stres atau kecemasan termasuk kedalam salah satu golongan emosi yang dapat mempengaruhi perilaku dan fisiologik seseorang.

Penelitian geografi emosi tentang COVID-19 pada siswa SMPN ini belum ditemukan secara spesifik di Indonesia, padahal aspek ini sangat penting pada anak yang dapat mempengaruhi tahapan perkembangan pada anak terutama anak usia remaja. Dalam hal 
ini, meskipun sudah ada penelitian sebelumnya tentang COVID-19 namun masih sedikit proporsi khususnya tentang geografi emosi pada anak SMP. Adapun tujuan dari penelitian ini adalah untuk mengidentifikasi geografi emosi tentang COVID-19 pada siswa.

\section{Metode}

Desain penelitian yang digunakan adalah menggunakan pendekatan kuantitatif yaitu untuk mengidentifikasi geografi emosi tentang COVID-19 pada siswa. Populasi dalam penelitian ini adalah adalah seluruh siswa SMPN 8 Kota Cimahi yaitu sebanyak 1640 siswa. Jumlah sampel yang digunakan sesuai perhitungan rumus slovin sebanyak 322. Namun saat mengumpulkan data siswa mengisi google form terdapat 328 siswa. Alat pengumpul data menggunakan instrumen baku COVID-19 Stress Scales (CSS) tahun 2020 dengan item pernyataan sebanyak 36 . Peneliti mengadaptasi dari jurnal taylor 2020, dengan cara mentranslate instrumen kedalam bahasa Indonesia. Teknik pengumpulan data yang dilakukan yaitu menyebarkan instrumen kepada siswa secara online melalui link google form. Berdasarkan hasil validitas dan uji reliabilitas instrumen menunjukkan bahwa nilai Alpha Cronbach=0,95 yang artinya bahwa instrumen ini reliabel dan setiap butir pernyataan hasilnya valid. Analisis data menggunakan analisis univariat.

Hasil

Hasil penelitian menunjukkan bahwa sebagian besar siswa berusia 14 Tahun yaitu $36.9 \%$ dan berjenis kelamin perempuan yaitu 55,2\% (Tabel 1). Geografi emosi siswa paling tinggi nilai rata rata yaitu berada pada domain Xenophobia dengan nilai rata-rata sebesar 3,394 dan selanjutnya adalah domain danger dengan nilai rata-rata 3,327 . Untuk nilai rata rata yang paling rendah yaitu berada pada domain Compulsive Checking degan nilai ratarata 2,107 (Tabel 2).

Tabel 1 Distribusi Frekuensi Karakteristik Responden

\begin{tabular}{|c|c|c|}
\hline Variabel & Frekuensi & Persentase \\
\hline \multicolumn{3}{|l|}{ Usia } \\
\hline - 12 & 56 & 17,1 \\
\hline - 13 & 98 & 29,9 \\
\hline - 14 & 120 & 36,9 \\
\hline - 15 & 47 & 14,3 \\
\hline - 16 & 7 & 2,1 \\
\hline \multicolumn{3}{|l|}{ Jenis Kelamin } \\
\hline - Laki-laki & 147 & 44,8 \\
\hline - Perempuan & 181 & 55,2 \\
\hline
\end{tabular}


Tabel 2. Distribusi Geografi Emosi berdasarkan Domain

\begin{tabular}{lcc}
\hline \multicolumn{1}{c}{ Domain } & Mean & Std Deviasi \\
\hline Danger & 3,327 & 1,326 \\
Contamination & 2,856 & 1,43 \\
Xenophobia & 3,394 & 1,29 \\
Socio-economic Consequences & 3,002 & 1,35 \\
Compulsive Checking & 2,107 & 1,251 \\
Traumatic Stress & 2,675 & 1,271 \\
\hline
\end{tabular}

\section{Pembahasan}

Berdasarkan karakteristik usia siswa SMP VIII Cimahi berada pada katagori remaja awal, dimana masa remaja dapat dibagi menjadi 3 golongan yaitu Remaja awal (12-15 tahun), remaja tengah (16-18 tahun) dan remaja akhir yaitu 19-20 tahun. ${ }^{14}$ Dalam masa remaja ini, emosi remaja berfluktuasi, remaja menunjukkan keberagaman minat yang luas, peningkatan keterampilan fisik serta kognitif membuat mereka ikut serta dalam aktivitas yang semakin sulit dan kompleks. ${ }^{15}$ Oleh karena itu peranan orang tua sangat penting salah satunya dalam pembentukan konsep diri pada anak. Cara orang tua mengasuh anaknya maka akan berpengaruh terhadap anak dalam menilai dirinya. Jika anak mendapat pengalaman yang baik dalam keluarga, maka anak dapat mengembangkan dan menilai dirinya secara baik pula. Kehangatan dalam keluarga berperanan penting bagi perkembangan konsep diri anak. Adanya rasa kehangatan dalam hubungan anak dan orang tua maka anak mempunya sikap sosial, kooperatif,emosinya stabil menerima dirinya sendiri dan menghargai orang lain. Pada masa pandemi COVID-19 Ini yang sifat wabahnya tiba-tiba dan derajat keparahan, menyebabkan orang mengalami kecemasan, depresi dan reaksi stres lainnya.

Dalam penelitian ini hasil analisis dari domain geografi emosi yang terdiri dari danger, contaminasi, xenophobia, social economic consequences, compulsive_checking, traumatic stress didapatkan bahwa nilai rata- rata siswa yang paling tinggi berada pada domain Xenophobia dengan nilai rata-rata sebesar 3,394. Hal ini dapat disebabkan karena COVID-19 merupaka hal yang baru atau asing sehingga siswa belum mengetahui banyak. Dalam kehidupan sehari-hari seringkali orang melihat emosi dari sisi negatif. Emosi dimaknakan dengan kata-kata emosional yang selanjutnya diwujudkan dalam berbagai perilaku yang tidak baik 
seperti kata-kata kotor suara keras bahkan tingkah laku agresif seperti memukul, memecahkan barang dan kata-kata yang menyakitkan hati orang. Dalam hal ini emosi dasar dari ketakutan (Xenophobia) diantaranya cemas, ngeri, khawatir, gelisah, merinding, ragu-ragu, malu dan cemburu. Selain itu emosi dapat dilihat juga dari sisi positif yang dapat bermanfaat bagi orang lain Emosi merupakan keadaan terangsang (aroused state) pada situasi atau kejadian. Keadaan tersebut memiliki komponen fisiologik, situasional,dan komponen kognitif. Emosi berkaitan dengan pengalaman subjektif, artinya perwujudan emosi tergantung pada respon yang diberikan oleh masingmasing individu. Secara garis besar emosi digolongkan menjadi dua golongan yaitu emosi positif dan emosi negatif. emosi positif seperti bahagia, senang, gembira dan cinta. Emosi negaif seperti takut, marah sedih dan cemas. Adapun ekspresi emosi seseorang dapat dilihat dari kata-kata atau verbal dan tingkah laku nonverbal orang yang bersangkutan. ${ }^{14}$

Ketakutan akan COVID-19 juga menjadi kontributor paling kuat dalam menentukan kesejahteraan. Kurangnya informasi mengenai penyebab penyakit, alasan pasti timbulnya pandemi, penularan yang cepat, kurangnya obat dan vaksin, dan tingkat ketidakpastian yang tinggi telah menyebabkan meningkatnya ketakutan di antara orang-orang di seluruh dunia. Perubahan langsung seperti karantina diri, jarak sosial, penyebaran rumor melalui media sosial, beban informasi yang salah dan pembatasan dalam bepergian menambah ketakutan dan stres, sehingga menyebabkan kekhawatiran dan kegelisahan yang berdampak buruk pada kesejahteraan. ${ }^{16}$ Hasil penelitian mengatakan bahwa ketakutan akan COVID-19, xenophobia dan kolektivisme berhubungan dengan kesejahteraan. ${ }^{17}$

Respon emosional yang disebabkan oleh stres pada dasarnya merupakan serangkaian pengalaman emosional yang menyertai orang dalam keadaan emosi negatif seperti depresi, kecemasan, panik, kekecewaan atau ketakutan. Perubahan perilaku utama yang disebabkan oleh stres adalah kegelisahan, kurangnya perhatian, berkurangnya kemampuan memecahkan masalah, lambat tindakan, sering marah, perilaku paksa (desinfeksi berlebihan dan cuci tangan berulang kali), mudah menangis, merokok, penyalahgunaan alkohol, dan lain-lain. ${ }^{7}$

Anak-anak dan remaja merasa lebih cemas dan tertekan sejak virus muncul. Banyak kekhawatiran dari anak-anak dan remaja adalah takut 
terkena atau menyebarkannya. Anakanak kehilangan teman sekolah dan anggota keluarga lain, juga lebih banyak terjadi pertengkaran di rumah. Anakanak menderita ketika tidak ada ruang yang tenang untuk belajar, atau ketika merasa terlalu terorganisir oleh orang tua. $^{13}$

\section{Kesimpulan}

\section{Xenophobia}

(Ketakutan)

merupakan geografi emosi yang dominan. Xenophobia yang berhubungan dengan penyakit, ketakutan akan konsekuensi sosialekonomi pandemi, pemeriksaan kompulsif dan pencarian jaminan mengenai ancaman terkait pandemi, dan gejala stres traumatis tentang pandemi seperti mimpi buruk dan pikiran yang terganggu.

\section{Saran}

Anak remaja yang mengalami cemas, takut, tertekan, merasa tidak tenang, dan khawatir itu termasuk kedalam kategori emosi. Mengingat stres atau kecemasan merupakan hal yang sangat penting, jangan sampai berlarut-larut karena dapat berpengaruh terhadap kesehatan fisik dan mental anak. Oleh karena itu peranan orang tua dan kehangatan dalam keluarga sangat penting salah satunya dapat berdampak pada pembentukan dan perkembangan konsep diri anak.

\section{Ucapan Terima Kasih}

Penulis ingin mengucapkan terima kasih kepada semua responden yang telah berbagi pengalaman dan pihak Sekolah SMPN VIII Cimahi yang telah membantu dalam penelitian ini.

\section{Daftar Pustaka}

1. ALMI (Akademi Ilmuan Muda Indonesia). Apa Bedanya Pandemi, Epidemi dan Wabah [Internet]. 2020. Available from: https://almi.or.id/2020/03/12/apabedanya-pandemi-epidemi-danwabah/

2. Corky Siemaszko. Coronavirus outbreak labeled a pandemic by World Health Organization [Internet]. 2020. Available from: https://www.nbcnews.com/health/h ealth-news/coronavirus outbreaklabeledpandemi -worldhealth-organization-n1155741

3. GTPP (Gugus Tugas Percepatan Penangan) COVID-19. Data Sebaran Global dan Nasional [Internet]. 2020. Available from: https://covid19.go.id/

4. WHO. Coronavirus [Internet]. 2020. Available from: https://www.who.int/ health-topics/ coronavirus\#tab=tab

5. PICC (Pusat Informasi Covid-19 Cimahi). PICC [Internet]. 2020. 
Available from: https://covid19. cimahikota.go.id

6. Qiu J, Shen B, Zhao M, Wang Z, Xie $\mathrm{B}, \mathrm{Xu}$ Y. A nationwide survey of psychological distress among Chinese people in the COVID-19 epidemic: Implications and policy recommendations.

General

Psychiatry. 2020.

7. Wang Y, Di Y, Ye J, Wei W. Study on the public psychological states and its related factors during the outbreak of coronavirus disease 2019 (COVID-19) in some regions of China. Psychol Heal Med. 2021;26(1):13-22.

8. Cheng SKW, Wong CW, Tsang J, Wong KC. Psychological distress and negative appraisals in survivors of severe acute respiratory syndrome (SARS). Psychol Med. 2004;

9. G.J. R, R. A, L. P, S. W. Public perceptions, anxiety, and behaviour change in relation to the swine flu outbreak: Cross sectional telephone survey. BMJ. 2009;

10. Wheaton MG, Abramowitz JS, Berman NC, Fabricant LE, Olatunji BO. Psychological predictors of anxiety in response to the $\mathrm{H} 1 \mathrm{~N} 1$ (swine flu) pandemic. Cognit Ther Res. 2012;

11. Taylor S. The psychology of pandemics: Preparing for the next global outbreak of infectious disease. Newcastle upon Tyne: Cambridge Scholars Publishing. Cambridge Scholars. 2019.

12. Taylor S, Landry CA, Paluszek MM, Fergus TA, McKay D, Asmundson GJG. Development and initial validation of the COVID Stress Scales. J Anxiety Disord. 2020;

13. NSPCC Learning. What children are saying to child line about corona virus [Internet]. 2020. Available from:

https://learning.nspcc.org.uk/resear ch-resources/2020/childline-

briefing-coronavirus

14. Saam Z Wahyuni. Psikologi Keperawatan. Jakarta: Rajagrafindo Persada; 2014.

15. Wong, D.L., Hockenberry, M., Wilson, D., Winkelstein, M.L., \& Schwartz P. Buku ajar keperawatan pediatrik edisi 6. Jakarta: EGC; 2009.

16. Banerjee D. The impact of Covid -19 pandemic on elderly mental health. Int J Geriatr Psychiatry. 2020;

17. Ahuja KK, Banerjee D, Chaudhary K, Gidwani C. Fear, xenophobia and collectivism as predictors of well-being during Coronavirus disease 2019: An empirical study from India. Int $\mathrm{J}$ Soc Psychiatry. 2021;67(1):46-53. 